\title{
Association of smoking status, cumulative smoking, duration of smoking cessation, age of starting smoking, and depression in Korean adults
}

Woo-Jun Yun ${ }^{1}$, Min-Ho Shin ${ }^{1}$, Sun-Seog Kweon ${ }^{1,2}$, So-Yeon Ryu ${ }^{3}$ and Jung-Ae Rhee ${ }^{1^{*}}$

\begin{abstract}
Background: Many previous studies did not sufficiently control for several confounding factors that may affect the association between smoking and depression, such as socioeconomic status. We investigated the association between depression and smoking status, smoking exposure, duration of smoking cessation, and age of starting smoking while controlling for socioeconomic factors.
\end{abstract}

Methods: This study was based on a community health survey performed in Jeollanam-do, South Korea, between September and November 2009. In total, 20,084 subjects (9,118 males and 10,966 females) were included in the analysis. Information on smoking characteristics, such as smoking status, pack-years of smoking, and age of starting smoking, was collected using a standardized questionnaire. Depression was defined using the Korean CES-D score.

Results: The odds ratios (ORs) of depression were 1.35 (0.92-1.98) for former smokers and 1.77 (1.27-2.48) for current-smokers among males, and 2.67 (1.38-5.16) for former smokers and $3.72(2.11-6.54)$ for current-smokers among females, after adjusting for other confounding factors. Compared to light smoking, heavy smoking was significantly associated with depression in males [OR $=3.97,95 \%$ confidence interval $(\mathrm{Cl})=1.42-11.14]$, but not in females $(\mathrm{OR}=1.24,95 \% \mathrm{Cl}=0.73-2.09)$. No significant associations between depression and age of starting smoking and duration of smoking cessation were observed among former smokers.

Conclusions: Our data demonstrate that smoking is strongly associated with depression, particularly among females. These findings suggest that depression prevention may need to be combined with smoking prevention and that different strategies may be needed for males and females.

\section{Background}

Epidemiologic [1-4] and clinical [5,6] studies have reported a strong association between smoking and depression. Several explanations for this association have been proposed.

The first is that underlying environmental or genetic factors predispose individuals to both smoking and depression [2,7-9]. The second is that depression leads to smoking. Several studies reported that smoking may increase as a result of self-medication for depression [10-12]. The third is that smoking itself increases the

\footnotetext{
* Correspondence: jarhee@healthis.or.kr

${ }^{1}$ Department of Preventive Medicine, Chonnam National University Medical School, Hak-1-dong, Dong-gu, Gwangju 501-746, Republic of Korea Full list of author information is available at the end of the article
}

risk of depression [13-18]. Some studies found that smoking among adolescents increased the risk of depression, and another reported that smoking was highly associated with depression in adults. However, in these studies, many confounding factors, such as socioeconomic status, which may affect the association between smoking and depression, were not sufficiently controlled. Furthermore, to our knowledge, no previous study has simultaneously evaluated several aspects of smoking status, including the amount of smoking, age of starting smoking, and duration of smoking cessation.

The objective of this study was to investigate the cross-sectional association between smoking and depression after controlling for socioeconomic factors and many aspects of smoking in population-based subjects.

\section{Ciomed Central}




\section{Methods}

\section{Subjects}

This study was based on a community health survey performed in Jeollanam-do, South Korea, between September and November 2009. This population-based cross-sectional survey was designed to investigate the health status, health behaviors, use of medical facilities, quality of life, and socioeconomic state of the community. A complex, multistage, probability sampling design was used to select participants. The study included 20,097 subjects aged 19-105 years. Thirteen subjects were excluded from the study because of missing smoking status information and the Center for Epidemiological Studies-Depression Scale (CES-D) score. Finally, the analysis included 20,084 subjects (9,118 males and 10,966 females). No institutional review board approval was required for this study because the data are available for public use and void of identifiers.

\section{Definition of depression}

The CES-D is a short self-report scale designed to measure depression in the general population and is widely used for epidemiologic studies on depression. The scale asks about the existence of 20 symptoms during the last week; scores range from 0 to 60, with higher scores indicating greater depression [19].

Cho et al.. translated the CES-D scale into Korean, paying attention to culturally different modes of expression of depressive feelings and thoughts. They reported that the Korean CES-D was reliable and valid for the Korean population, and reported that the appropriate cutoff point for depression was a Korean CES-D score of 21 [20]. Here, we defined depression as a Korean CES-D score $\geq 21$.

\section{Definition of smoking}

Smoking status was classified as never-smokers (smoked $<100$ cigarettes in their lifetime and not currently smoking), former smokers (smoked $\geq 100$ cigarettes in their lifetime and currently a nonsmoker), and current-smokers (smoked $\geq 100$ cigarettes in their lifetime and currently a smoker). Status of smoking exposure was classified as light smoker ( $\leq 10$ cigarettes daily), moderate smoker $(\leq 20$ cigarettes daily), and heavy smoker ( $>20$ cigarettes daily). Pack-years of smoking were calculated by multiplying the number of years smoked by the average number of packs per day. Based on the age of starting smoking, subjects were classified as $\leq 19$ years, $20-24$ years, and $\geq 25$ years, and compared with never-smokers. Based on the duration of smoking, age of starting smoking, and age of former smokers, we calculated the duration of smoking cessation. Former-smokers were classified as < $<$ years, 5-9 years, $10-19$ years, and $\geq 20$ years, and compared with currentsmokers.

\section{Covariates}

Household income was determined by each subject's reported monthly household income in Korean won and categorized as: < one million won; < two million won; $<$ three million won; and $\geq$ three million won. Education status was categorized as uneducated, elementary and middle school, high school, and college. Marital status was coded into two categories (married/partnered, never married/non-partnered). Job status was coded into three categories (nonmanual, manual, others) according to the Korean Standard Classification of Occupation (KSCO).

Monthly drinking was defined as drinking alcohol at least once per month in the previous year. We used monthly drinking as drinking status (yes/no) in this study. Hypertension was defined as the use of medication for hypertension. Diabetes was defined as the use of medication for diabetes. Body mass index (BMI) was calculated using self-reported height and weight.

\section{Statistical analysis}

All analysis in this study was performed separately for both sexes because of differences in smoking status and depression rate according to sex, as well as the interaction effects between sex and smoking status on depression. The characteristics of the study population are expressed as the mean \pm standard error or number (weighted percentage). Multivariate survey logistic regression was used to evaluate the association of smoking characteristics (e.g., smoking status, cumulative smoking exposure, age of starting smoking, and duration of smoking cessation) with depression. The odds ratio (OR) and 95\% confidence interval (CI) was calculated in unadjusted and multivariate-adjusted models after adjusting for age, income status, education status, marital status, job status, drinking status, hypertension, diabetes mellitus, cerebrovascular disease (CVD), BMI, and physical activity. The multivariate-adjusted model of smoking exposure among current-smokers was further adjusted for the amount of smoking, and the multivariate-adjusted model of the duration of smoking cessation among former-smokers was further adjusted for pack-years of smoking. The multivariate-adjusted model of age of starting smoking among currentsmokers was additionally adjusted for th4e amount of smoking.

All statistical analyses were performed using STATA software, version 11.0 SE (STATA, College Station, TX, USA).

\section{Results}

\section{Characteristics of the study population}

Of the 20,084subjects analyzed, 9,118 (49.3\%) were male and 10,966 (50.6\%) female. The point prevalence of depression was $4.6 \%$ in males and $8.0 \%$ in females. Subjects 
with depression were significantly older than those without depression in both sexes (males: $46.5 \pm 0.4$ vs. $56.4 \pm 2$; females: $50.1 \pm 0.5$ vs. $58.6 \pm 1.8$ ). Subjects with depression had a significantly higher percentage of current/former smokers than subjects without depression in both sexes (males: $45.0 \%$ vs. $49.1 \%$; females: $1.6 \%$ vs. $7.8 \%)$.

Subjects with depression had significantly higher mean pack-years of smoking than those without depression in both sexes (males: $13.8 \pm 0.4$ vs. $20.3 \pm 2.4$; females: $0.2 \pm$ 0.2 vs. $1.3 \pm 0.5$ ). Subjects with depression did not exhibit a significantly lower mean age of starting smoking than those without depression in both sexes (males: $20.7 \pm 0.1$ vs. $20.8 \pm 0.6$; females: $31.0 \pm 2.0$ vs. $35.6 \pm 5.3)$.
Subjects with depression had a significantly longer duration of quitting smoking than those without depression in males, but not in females (males: $13.0 \pm 0.6$ vs. $17.9 \pm$ 3.9; females: $16.3 \pm 4.0$ vs. $15.5 \pm 6.5$ ) (Table 1).

\section{Smoking status and depression}

We found interaction effects between sex and current smoking on depression in the survey logistic regression analyses ( $p=0.009$ for interaction).

Currents smokers had a significantly higher risk of depression than those who had never smoked in both males $(\mathrm{OR}=1.77,95 \% \mathrm{CI}=1.27-2.48)$ and females $(\mathrm{OR}=3.72$, $95 \% \mathrm{CI}=2.11-6.54)$. However, former smokers had a significantly higher risk of depression than those who had

Table 1 General characteristics of the study population with and without depression $(n=20,084)$

\begin{tabular}{|c|c|c|c|c|}
\hline \multirow[t]{2}{*}{ Characteristics } & \multicolumn{2}{|c|}{ Men $(n=9,118)$} & \multicolumn{2}{|c|}{ Women $(n=10,966)$} \\
\hline & $\begin{array}{l}\text { Non-depression } \\
\quad(n=8,702)\end{array}$ & $\begin{array}{c}\text { Depression } \\
(n=416)\end{array}$ & $\begin{array}{c}\text { Non-depression } \\
(n=10,094)\end{array}$ & $\begin{array}{c}\text { Depression } \\
(\mathbf{n}=\mathbf{8 7 2})\end{array}$ \\
\hline Age (years) & $46.5 \pm 0.4$ & $56.4 \pm 2.1^{*}$ & $50.1 \pm 0.5$ & $58.6 \pm 1.8^{*}$ \\
\hline \multicolumn{5}{|l|}{ Smoking status } \\
\hline Never smokers & $2,687(30.9)$ & $99(22.1)^{*}$ & $9,843(97.7)$ & $798(89.3)^{\dagger}$ \\
\hline Former smokers & $2,333(24.0)$ & $138(28.7)$ & $76(0.3)$ & $23(2.8)$ \\
\hline Current smokers & $3,682(45.0)$ & $179(49.1)$ & $175(1.6)$ & $51(7.8)$ \\
\hline Pack-years of smoking & $13.8 \pm 0.4$ & $20.3 \pm 2.4^{*}$ & $0.2 \pm 0.2$ & $1.3 \pm 0.5$ \\
\hline Age of starting smoking & $20.7 \pm 0.1$ & $20.8 \pm 0.6$ & $31.0 \pm 2.0$ & $35.6 \pm 5.3$ \\
\hline Duration of smoking cessation & $13.0 \pm 0.6$ & $17.9 \pm 3.9^{*}$ & $16.3 \pm 4.0$ & $15.5 \pm 6.5^{*}$ \\
\hline \multicolumn{5}{|l|}{ Household Income } \\
\hline$<$ one million won & $2,494(20.1)$ & $260(53.6)^{*}$ & $3,735(26.7)$ & $538(53.2)^{*}$ \\
\hline$<$ two million won & $2,127(21.1)$ & $75(18.3)$ & $2,256(20.6)$ & $129(15.9)$ \\
\hline$<$ three million won & $1,655(21.8)$ & $27(9.7)$ & $1,647(19.2)$ & $94(15.0)$ \\
\hline$\geqq$ three million won & $2,421(36.8)$ & $53(18.2)$ & $2,450(33.3)$ & $110(15.7)$ \\
\hline \multicolumn{5}{|l|}{ Education level } \\
\hline Uneducated & $805(5.8)$ & $116(22.2)^{*}$ & $3,153(22.1)$ & $489(48.3)^{*}$ \\
\hline Elementary and Middle school & $3,360(28.3)$ & $176(38.0)$ & $3,497(29.4)$ & $209(22.5)$ \\
\hline High school and College & $4,537(65.8)$ & $123(39.7)$ & $3,441(48.4)$ & $174(29.0)$ \\
\hline \multicolumn{5}{|l|}{ Marital status } \\
\hline Married/partnered & $6,573(68.5)$ & $255(54.2)^{*}$ & $6,482(64.4)$ & $363(40.2)^{*}$ \\
\hline Never married/non-partnered & $2,129(31.4)$ & $160(45.7)$ & $3,611(35.5)$ & $509(59.7)$ \\
\hline \multicolumn{5}{|l|}{ Job status } \\
\hline Non-manual & $1,332(19.5)$ & $20(6.8)^{*}$ & $982(13.9)$ & $43(6.8)^{*}$ \\
\hline Manual & $5,814(61.2)$ & $155(37.1)$ & $4,518(36.9)$ & $237(25.1)$ \\
\hline Others & $1,558(19.2)$ & $241(56.0)$ & $4,594(49.0)$ & $592(68.0)$ \\
\hline Hypertension & $1,607(13.7)$ & $118(24.6)^{*}$ & $2,475(18.3)$ & $319(33.8)^{*}$ \\
\hline Diabetes Mellitus & $715(6.5)$ & $63(14.5)^{\dagger}$ & $766(5.9)$ & $119(12.6)^{\dagger}$ \\
\hline Cerebrovascular disease & $363(3.0)$ & $65(8.9)^{*}$ & $413(3.2)$ & $100(9.8)^{*}$ \\
\hline Body Mass Index (BMI) & $24.0 \pm 0.2$ & $24.2 \pm 1.8$ & $24.6 \pm 0.4$ & $28.1 \pm 2.1^{*}$ \\
\hline Physical activity & $2,971(33.2)$ & $82(19.4)^{*}$ & $2,608(23.8)$ & $164(16.8)^{*}$ \\
\hline
\end{tabular}

Data are presented as mean (standard error) or unweighted number (weighted percent).

${ }^{*} p<0.001$

$+p<0.05$. 
never smoked in females $(\mathrm{OR}=2.67,95 \% \mathrm{CI}=1.38-5.16)$, but not in males (Table 2).

Current smoking exposure had a significantly higher risk for depression among current-smokers in females, but not in males. Compared to light-smokers, heavysmokers had a significantly higher risk of depression in females $(\mathrm{OR}=3.97,95 \% \mathrm{CI}=1.42-11.14)$. However, the OR of heavy-smokers for depression in males was 1.24 (95\% CI $=0.73-2.09)$ (Table 3).

Age of starting smoking did not have a significantly higher risk for depression among current-smokers. Compared to those who started smoking at $\leq 19$ years, the ORs of those who started smoking at 20-24 years were $0.81(95 \% \mathrm{CI}=0.52-1.27)$ in males and $2.18(95 \%$ $\mathrm{CI}=0.37-12.69)$ in females. ORs of those who started smoking at $>20$ years were $1.15(95 \% \mathrm{CI}=0.61-2.17)$ in males and $0.95(95 \% \mathrm{CI}=0.22-3.93)$ in females (Table 4).

Duration of smoking cessation among former smokers did not exhibit a significantly lower risk of depression in males. We did not evaluate the relationships between the duration of smoking cessation and depression in females because the number of formersmokers among females was small. Compared to those who quit smoking $<5$ years, the OR of those who quitted smoking $\geq 20$ years was $0.92(95 \% \mathrm{CI}=$ $0.39-2.14$ ) in males (Table 5).

\section{Discussion}

The results of this study demonstrated a stronger association between smoking status and depression in women than in men. However, the dose-response relationship for smoking and depression among current-smokers was only significant in females. No significant associations of the age of starting smoking and duration of smoking

Table 2 Odds ratio for depression according to smoking status

\begin{tabular}{|c|c|c|c|}
\hline & \multirow{2}{*}{$\begin{array}{c}\text { Smoking status } \\
\begin{array}{c}\text { Never smokers } \\
(n=13,427)\end{array}\end{array}$} & \multirow{2}{*}{$\begin{array}{c}\text { Smoking status } \\
\begin{array}{c}\text { Former smokers } \\
(n=2,570)\end{array}\end{array}$} & \multirow[b]{2}{*}{$\begin{array}{l}\text { Current smokers } \\
\quad(n=4,087)\end{array}$} \\
\hline & & & \\
\hline Men & $(n=2,786)$ & $(n=2,471)$ & $(n=3,861)$ \\
\hline Unadjusted & 1.00 (Reference) & $1.66(1.18-2.35)$ & $1.52(1.11-2.09)$ \\
\hline $\begin{array}{l}\text { Multivariate- } \\
\text { adjusted** }\end{array}$ & 1.00 (Reference) & $1.35(0.92-1.98)$ & $1.77(1.27-2.48)$ \\
\hline Women & $(n=10,641)$ & $(n=99)$ & $(n=226)$ \\
\hline Unadjusted & 1.00 (Reference) & $4.68(2.38-9.20)$ & $5.30(3.30-8.50)$ \\
\hline $\begin{array}{l}\text { Multivariate- } \\
\text { adjusted* }\end{array}$ & 1.00 (Reference) & $2.67(1.38-5.16)$ & $3.72(2.11-6.54)$ \\
\hline
\end{tabular}

Data are presented as mean (standard error) or odds ratio (95\% confidence interval).

*Adjusted for age, income status, education status, marital status, job status, drinking status, BMI, physical activity, Hypertension, Diabetes mellitus, and Cerebrovascular disease.
Table 3 Odds ratio for depression according to smoking exposure among current smokers

\begin{tabular}{lccc}
\hline & \multicolumn{2}{l}{ Cumulative smoking exposure } & \\
\cline { 2 - 4 } & $\begin{array}{c}\text { Light } \\
\text { smokers } \\
{[\leqq \mathbf{1 0 . 0}} \\
(\mathbf{n}=\mathbf{6 1 5})\end{array}$ & $\begin{array}{c}\text { Moderate } \\
\text { smokers } \\
{[\mathbf{1 0 . 1}-\mathbf{2 0 . 0}} \\
(\mathbf{n}=\mathbf{1 , 2 5 9 )}\end{array}$ & $\begin{array}{c}\text { Heavy } \\
\text { smokers } \\
{[\mathbf{2 0 . 0 ]}} \\
(\mathbf{n}=\mathbf{2 , 2 1 3 )}\end{array}$ \\
\hline Men & $(\mathrm{n}=515)$ & $(\mathrm{n}=1,181)$ & $(\mathrm{n}=2,164)$ \\
\hline Unadjusted & 1.00 (Reference) & $0.53(0.28-0.98)$ & $0.83(0.47-1.45)$ \\
\hline Multivariate- & 1.00 (Reference) & $0.71(0.40-1.26)$ & $1.24(0.73-2.09)$ \\
adjusted* & $(\mathrm{n}=100)$ & $(\mathrm{n}=78)$ & $(\mathrm{n}=49)$ \\
\hline Women & 1.00 (Reference) & $0.58(0.19-1.69)$ & $3.65(1.15-11.59)$ \\
\hline Unadjusted & 1.00 (Reference) & $0.63(0.23-1.69)$ & $3.97(1.42-11.14)$ \\
\hline Multivariate- & & & \\
adjusted* & &
\end{tabular}

Data are presented as mean (standard error) or odds ratio (95\% confidence interval).

${ }^{*}$ Adjusted for age, income status, education status, marital status, job status, drinking status, BMI, physical activity, Hypertension, Diabetes mellitus, and Cerebrovascular disease.

cessation with depression were observed among formersmokers.

In this study, the smoking rate in women was lower than that in men. The gender difference in smoking might be due to the effects of socio-cultural factors. Sex role norms and general expectations concerning genderappropriate behavior have had a variety of effects on gender differences in smoking [21]. Traditional sex roles lead to social pressure against women smoking [21]. Additionally, differences in the demographic and socioeconomic characteristics of smokers and non-smokers have been reported [22-24]. The relationship between smoking and depression could be affected by these factors. However, it seems unlikely that these factors affected our results, as we adjusted for them in our analysis.

Table 4 Odds ratio for depression according to age of starting smoking among current smokers

\begin{tabular}{|c|c|c|c|}
\hline & \multicolumn{3}{|c|}{ Age of starting smoking } \\
\hline & $\begin{array}{l}<19 \text { years } \\
(n=1,281)\end{array}$ & $\begin{array}{c}20-24 \text { years } \\
(n=2,014)\end{array}$ & $\begin{array}{c}\geqq 25 \text { years } \\
(n=789)\end{array}$ \\
\hline Men & $(n=1,259)$ & $(n=1,980)$ & $(n=618)$ \\
\hline Unadjusted & 1.00 (Reference) & $0.79(0.51-1.22)$ & $1.51(0.84-2.71)$ \\
\hline $\begin{array}{l}\text { Multivariate- } \\
\text { adjusted* }\end{array}$ & 1.00 (Reference) & $0.81(0.52-1.27)$ & $1.15(0.61-2.17)$ \\
\hline Women & $(n=22)$ & $(n=34)$ & $(n=171)$ \\
\hline Unadjusted & 1.00 (Reference) & $1.37(0.24-7.82)$ & $0.97(0.21-4.45)$ \\
\hline $\begin{array}{l}\text { Multivariate- } \\
\text { adjusted* }\end{array}$ & 1.00 (Reference) & $2.18(0.37-12.69)$ & $0.95(0.22-3.93)$ \\
\hline
\end{tabular}

Data are presented as mean (standard error) or odds ratio ( $95 \%$ confidence interval).

*Adjusted for age, income status, education status, marital status, job status, amount of smoking, drinking status, BMl, physical activity, Hypertension,

Diabetes mellitus, and Cerebrovascular disease. 
Table 5 Odds ratio for depression according to duration of smoking cessation among former smokers in men

\begin{tabular}{|c|c|c|c|c|}
\hline & \multicolumn{4}{|c|}{ Duration of smoking cessation } \\
\hline & $<5$ years $(n=636)$ & $5-9$ years $(n=436)$ & $10-19$ years $(n=640)$ & $\geqq 20$ years $(n=760)$ \\
\hline \multicolumn{5}{|l|}{ Men } \\
\hline Unadjusted & 1.00 (Reference) & $0.92(0.52-1.64)$ & $1.48(0.74-2.94)$ & $1.83(0.96-3.50)$ \\
\hline Multivariate-adjusted* & 1.00 (Reference) & $0.71(0.37-1.34)$ & $1.32(0.60-2.88)$ & $0.92(0.39-2.14)$ \\
\hline
\end{tabular}

The CES-D is an adequate screening instrument for depressive disorder in the population [25-28]. We used a CES-D cutoff score of 21 as the definition of depression. Although the CES-D has low sensitivity and specificity for minor depression, it is excellent for use as a screening instrument for major depression, and the optimum cutoff point for the CES-D was found to be 21 [25]. Cho et al. also reported that a CES-D score of 21 most effectively detected a range of depressive symptoms during screening. They suggested that the higher cutoff point in Korea than in Western countries might be due to differences in the expression of affect, especially the suppression of positive affect, in cultures based on Confucian ethics [20].

Previous reports have proposed mechanisms for the association of smoking with depression. One pharmacological explanation for the influence of smoking on depression is that a reduction in monoamine oxidase $B$ (MAO B) activity might synergize with nicotine to produce the diverse behavioral and epidemiological effects of smoking. The brains of smokers showed a $40 \%$ decrease in MAO B level relative to nonsmokers or former-smokers [29]. Another explanation is that vulnerability to depression is related to certain factors. Nicotine is known to affect the neurotransmitters involved in major depression [30]. Nicotine use might increase vulnerability to depression [31], and dysregulation of the dopaminergic system in an addictive state is a plausible mechanistic pathway to depressive vulnerability [32]. A further explanation is that smoking generates free radicals, causing lipid peroxidation, oxidation of proteins, and other tissue damage in smokers [33]. Depression has been associated with elevated reactive oxidative species such as anti-oxidative enzyme activities and lipid peroxidation [34].

Our data suggest that associations between smoking status and depression were more likely in females. Some studies reported a strong relationship between smoking and depression in females, rather than in males. Others reported a gender-specific effect, and that females showed a much greater smoking-depression relationship than males in both adolescents [14,35] and adults $[15,16]$. However, some studies have reported conflicting results. Nakata et al. reported that gender did not modify the effects of smoking on depression [36], and in some studies, an increased risk of depression was observed in male, but not female, smokers [37-39]. One possible explanation for this gender difference is that female smokers may have a lower threshold for depression than male smokers. McKee et al. reported that stressful life events were more strongly related to smoking in females than in males [40]. However, gender-specific effects in the smoking-depression relationship remain incompletely understood.

In this study, current-smokers had a higher risk of depression than never-smokers among both males and females. Although no statistically significant association was seen in males, former-smokers had a lower risk of depression than current-smokers. Wisebeck et al. reported that former-smokers carried a risk of depression that was significantly lower than that of currentsmokers, but higher than in never-smokers [41]. They suggested that their results are in accordance with the hypothesis that smoking cessation was an effective way to reduce the risk of depression, and if so, depression should be less frequent in former-smokers who stopped smoking a long time ago compared to those who stopped recently [41]. However, in their study, the difference between the association of distant (first 3 years) smoking cessation and recent (within 1 year) smoking cessation with depression was not significant [41]. Mykletun et al. also reported no associations between depression and time since cessation in former-smokers [38]. They explained that although a trend toward a lower prevalence of depression with time since cessation was detected, it was not statistically significant [38]. Our results are similar; the risk of depression did not significantly decrease with increasing duration of smoking cessation in both males and females. We also evaluated the relationship between the age of starting smoking and depression, and no significant increased risk of depression was observed according to decreasing age of starting smoking. Some studies have reported that smoking during adolescence predicted depression later in life compared with never-smokers $[14,42,43]$. However, to our knowledge, no study had evaluated the relationship 
between the age of starting smoking and depression among current-smokers. We suggest that current smoking status is a more important factor for risk of depression.

If a physiologic link indeed exists between smoking and the subsequent development of depression, then it would be reasonable to expect that evidence of this link would became more pronounced as the number of cigarettes consumed increases. Klungsøyr et al. reported a dose-response relationship with an increasing risk for former-smokers and for increasing numbers of cigarettes smoked per day for current-smokers, and also for an increasing number of smoking-years [18]. Pasco et al. reported that compared with nonsmokers, the odds for major depressive disorder increases by 1.47 -fold for females who smoked 11-20 cigarettes per day and more than doubled for those who smoked $>20$ cigarettes per day [44]. However, in their studies, dose-response relationships of smoking were evaluated by comparing them with never-smokers. Duncan and Reese reported very little evidence that smoking intensity was related to depression in smokers [45]. In their study, smoking an extra pack of cigarettes per month was associated with a statistically nonsignificant 0.02 increase in male CES-D scores and a 0.01 increase in female CES-D scores after controlling for smoking status [45]. In the present study, no dose-response relationship of smoking with depression was observed among current-smokers in males, but female heavy smokers had a higher risk of depression. We suggest that this difference might be related to a gender-specific effect of smoking on depression.

\section{Conclusions}

Our data demonstrate that smoking is strongly associated with depression, particularly among females. However, a dose-response relationship was observed only between smoking and depression in females, and not in males, and duration of smoking cessation and age of starting smoking were not significantly associated with depression. Further large population-based prospective studies are needed to confirm the causal effects of smoking on depression. These findings suggest that depression prevention may need to be combined with smoking prevention and that different strategies in males and females may be necessary.

\section{Competing interests}

The authors declare that they have no competing interests.

\section{Authors' contributions}

WJY collected data, analyzed data and drafted the manuscript. MHS, SSK, SYR and JAR participated in the study design, data analysis and also reviewed the manuscript. All authors read and approved the final manuscript to be published.

\section{Author details}

'Department of Preventive Medicine, Chonnam National University Medical School, Hak-1-dong, Dong-gu, Gwangju 501-746, Republic of Korea. ${ }^{2} J$ Jeonnam Regional Cancer Center, Chonnam National University Hwasun Hospital, Jeollanamdo 519-809, Republic of Korea. ${ }^{3}$ Department of Preventive Medicine, Chosun University Medical School, Gwangju 501-759, Republic of Korea.

Received: 13 February 2012 Accepted: 20 July 2012

Published: 31 August 2012

\section{References}

1. Glassman AH, Helzer JE, Covey LS, Cottler LB, Stetner F, Tipp JE, Johnson J: Smoking, Smoking Cessation, and Major Depression. JAMA 1990, 264(12):1546-1549.

2. Kendler KS, Neale MC, MacLean CJ, Heath AC, Eaves L, Kessler RC: Smoking and Major Depression: A Causal Analysis. Arch Gen Psychiatry 1993, 50(1):36-43.

3. Degenhardt L, Hall W: The relationship between tobacco use, substance-use disorders and mental health: results from the National Survey of Mental Health and Well-being. Nicotine Tob Res 2001, 3(3):225-234.

4. Anda RF, Williamson DF, Escobedo LG, Mast EE, Giovino GA, Remington PL: Depression and the Dynamics of Smoking. JAMA 1990, 264(12):1541-1545.

5. Glassman AH, Stetner F, Walsh BT, Raizman PS, Fleiss JL, Cooper TB, Covey LS: Heavy Smokers, Smoking Cessation, and Clonidine. JAMA 1988, 259(19):2863-2866.

6. Kandel DB, Davies M: Adult Sequelae of Adolescent Depressive Symptoms. Arch Gen Psychiatry 1986, 43(3):255-262.

7. Dierker LC, Avenevoli S, Stolar M, Merikangas KR: Smoking and Depression: An Examination of Mechanisms of Comorbidity. Am J Psychiatry 2002, 159(6):947-953.

8. Rohde P, Kahler CW, Lewinsohn PM, Brown RA: Psychiatric disorders, familial factors, and cigarette smoking: II. Associations with progression to daily smoking. Nicotine \& Tobacco Research 2004, 6(1):119-132.

9. Haarasilta LM, Marttunen MJ, Kaprio JA, Aro HM: Correlates of depression in a representative nationwide sample of adolescents (15-19 years) and young adults (20-24 years). Eur J Public Health 2004, 14(3):280-285.

10. Covey LS, Tam D: Depressive mood, the single-parent home, and adolescent cigarette smoking. Am J Public Health 1990, 80(11):1330-1333.

11. Breslau N, Peterson EL, Schultz LR, Chilcoat HD, Andreski P: Major Depression and Stages of Smoking: A Longitudinal Investigation. Arch Gen Psychiatry 1998, 55(2):161-166.

12. Patton GC, Carlin JB, Coffey C, Wolfe R, Hibbert M, Bowes G: Depression, anxiety, and smoking initiation: a prospective study over 3 years. $A m$ J Public Health 1998, 88(10):1518-1522.

13. Wu LT, Anthony JC: Tobacco smoking and depressed mood in late childhood and early adolescence. Am J Public Health 1999, 89(12):1837-1840

14. Goodman E, Capitman J: Depressive Symptoms and Cigarette Smoking Among Teens. Pediatrics 2000, 106(4):748-755.

15. Massak A, Graham K: Is the Smoking-Depression Relationship Confounded by Alcohol Consumption? An Analysis by Gender. Nicotine Tob Res 2008, 10(7):1231-1243.

16. Husky MM, Mazure CM, Paliwal P, McKee SA: Gender differences in the comorbidity of smoking behavior and major depression. Drug Alcohol Depend 2008, 93(1-2):176-179.

17. Munafò MR, Hitsman B, Rende R, Metcalfe C, Niaura R: Effects of progression to cigarette smoking on depressed mood in adolescents: evidence from the National Longitudinal Study of Adolescent Health. Addiction 2008, 103(1):162-171.

18. Klungsøyr O, Nygård JF, Sørensen T, Sandanger I: Cigarette Smoking and Incidence of First Depressive Episode: An 11-Year, Population-based Follow-up Study. Am J Epidemiol 2006, 163(5):421-432

19. Radloff LS: The CES-D Scale. Appl Psychol Meas 1977, 1(3):385-401.

20. Cho MJ, Kim KH: Use of the Center for Epidemiologic Studies Depression (CES-D) Scale in Korea. J Nerv Ment Dis 1998, 186(5):304-310.

21. Waldron I: Patterns and causes of gender differences in smoking. Soc Sci Med 1991, 32(9):989-1005. 
22. Laaksonen M, Rahkonen O, Karvonen S, Lahelma E: Socioeconomic status and smoking: analysing inequalities with multiple indicators. Eur J Public Health 2005, 15(3):262-269.

23. Huisman M, Van Lenthe FJ, Giskes K, Kamphuis CB, Brug J, Mackenbach JP: Explaining socio-economic inequalities in daily smoking: a social-ecological approach. Eur J Public Health 2011, 22(2):238-243.

24. Gray L, Leyland AH: Is the "Glasgow effect" of cigarette smoking explained by socio-economic status?: a multilevel analysis. BMC Publ Health 2009, 9:245.

25. Lyness JM, Noel TK, Cox C, King DA, Conwell Y, Caine ED: Screening for depression in elderly primary care patients. A comparison of the Center for Epidemiologic Studies-Depression Scale and the Geriatric Depression Scale. Arch Intern Med 1997, 157(4):449-454.

26. Dozeman E, van Schaik DJ, van Marwijk HW, Stek ML, van der Horst HE, Beekman AT: The center for epidemiological studies depression scale (CES-D) is an adequate screening instrument for depressive and anxiety disorders in a very old population living in residential homes. Int J Geriatr Psychiatry 2011, 26(3):239-246.

27. Beekman AT, Deeg DJ, Van Limbeek J, Braam AW, De Vries MZ, Van Tilburg W: Criterion validity of the Center for Epidemiologic Studies Depression scale (CES-D): results from a community-based sample of older subjects in The Netherlands. Psychol Med 1997, 27(1):231-235.

28. Lewinsohn PM, Seeley JR, Roberts RE, Allen NB: Center for Epidemiologic Studies Depression Scale (CES-D) as a screening instrument for depression among community-residing older adults. Psychol Aging 1997, 12(2):277-287.

29. Fowler JS, Volkow ND, Wang GJ, Pappas N, Logan J, MacGregor R, Alexoff D, Shea C, Schlyer D, Wolf AP, et al: Inhibition of monoamine oxidase B in the brains of smokers. Nature 1996, 379(6567):733-736.

30. Hall SM, Muñoz RF, Reus VI, Sees KL: Nicotine, negative affect, and depression. J Consult Clin Psychol 1993, 61(5):761-767.

31. Pomerleau OF, Pomerleau CS: Neuroregulators and the reinforcement of smoking: Towards a biobehavioral explanation. Neurosci Biobehav Rev 1984, 8(4):503-513.

32. Malhi GS, Berk M: Does dopamine dysfunction drive depression? Acta Psychiatr Scand 2007, 115:116-124.

33. Ozguner F, Koyu A, Cesur G: Active smoking causes oxidative stress and decreases blood melatonin levels. Toxicol Ind Health 2005, 21(10):21-26.

34. Bilici M, Efe H, Koglu MA, Uydu HA, Bekaroglu M, Deger O: Antioxidative enzyme activities and lipid peroxidation in major depression: alterations by antidepressant treatments. J Affect Disord 2001, 64(1):43-51.

35. Steuber TL, Danner F: Adolescent smoking and depression: Which comes first? Addict Behav 2006, 31(1):133-136.

36. Nakata A, Takahashi M, Ikeda T, Hojou M, Nigam JA, Swanson NG: Active and passive smoking and depression among Japanese workers. Prev Med 2008, 46(5):451-456.

37. Wang Y, Browne DC, Storr CL, Wagner FA: Gender and the tobaccodepression relationship: A sample of African American college students at a Historically Black College or University (HBCU). Addict Behav 2005, 30(7):1437-1441.

38. Mykletun A, Overland S, Aar Leif E, Liab H-M, Stewart R: Smoking in relation to anxiety and depression: Evidence from a large population survey: The HUNT study. Eur Psychiatry 2008, 23(2):77-84.

39. Korhonen T, Broms U, Varjonen J, Romanov K, Koskenvuo M, Kinnunen T, Kaprio J: Smoking behaviour as a predictor of depression among Finnish men and women: a prospective cohort study of adult twins. Psychol Med 2007, 37(05):705-715

40. McKee SA, Maciejewski PK, Falba T, Mazure CM: Sex differences in the effects of stressful life events on changes in smoking status. Addiction 2003, 98(6):847-855.

41. Wiesbeck GA, Kuhl HC, Yaldizli Ö, Wurst FM: Tobacco Smoking and Depression - Results from the WHO/ISBRA Study. Neuropsychobiology 2008, 57(1-2):26-31.

42. Brook JS, Schuster E, Zhang C: Cigarette smoking and depressive symptoms: a longitudinal study of adolescents and young adults. Psychol Rep 2004, 95(1):159-166.

43. Choi W, Patten C, Christian Gillin J, Kaplan R, Pierce J: Cigarette smoking predicts development of depressive symptoms among U.S. Adolescents. Ann Behav Med 1997, 19(1):42-50.
44. Pasco JA, Williams LJ, Jacka FN, Ng F, Henry MJ, Nicholson GC, Kotowicz MA, Berk M: Tobacco smoking as a risk factor for major depressive disorder: population-based study. Br J Psychiatry 2008, 193(4):322-326.

45. Duncan B, Rees DI: Effect of Smoking on Depressive Symptomatology: A Reexamination of Data from the National Longitudinal Study of Adolescent Health. Am J Epidemiol 2005, 162(5):461-470.

doi:10.1186/1471-2458-12-724

Cite this article as: Yun et al:: Association of smoking status, cumulative smoking, duration of smoking cessation, age of starting smoking, and depression in Korean adults. BMC Public Health 2012 12:724.

\section{Submit your next manuscript to BioMed Central and take full advantage of:}

- Convenient online submission

- Thorough peer review

- No space constraints or color figure charges

- Immediate publication on acceptance

- Inclusion in PubMed, CAS, Scopus and Google Scholar

- Research which is freely available for redistribution 